\title{
Epilepsy and Law
}

\section{Author Information: ROY G. BERAN}

\author{
M.D (University of NSW, Australia)., \\ F.R.A.C.P (Royal Australasian College of GP's, Australia)., \\ F.R.C.P (Royal College of Physicians, Edinburgh)., \\ F.R.A.C.G.P (Royal Australian College of Physicians, Australia)., \\ F.A.C.L.M.(Australian College of Legal Medicine, Australia), \\ F.A.F.P.H.M (Australian Faculty of Public Health Medicine (RACP)) \\ F.A.C.B.S. (Australasian College of Biomedical Sciences, Australia) \\ F.F.F.L.M. (Hon) (Faculty of Forensic and Legal Medicine (RCP - London)) \\ B Leg.S. (Macquarie University, Sydney Australia) \\ Grad. Dip. Tert. Ed. (New England University, Armidale, Australia) \\ Grad. Dip. Further Ed. (Adelaide College of Advanced Education, Australia), \\ M.H.L. (University of Sydney, Australia) \\ CONJOINT ASSOCIATE PROFESSOR UNIVERSITY OF NSW, AUSTRALIA
}

PROFESSOR, SCHOOL OF MEDICINE, GRIFFITH UNIVERSITY, BRISBANE, AUSTRALIA

LIVERPOOL HOSPITAL - DEPARTMENT OF NEUROLOGY

STRATEGIC HEALTH EVALUATORS

\section{Author's Contact Details:}

Address: Suite 5, level 6, 12 Thomas Street

Chatswood NSW 2067, Australia

Ph: +61029411 4991

Fax: +61 0294114991

Roy.Beran@unsw.edu.au

(preferred method of communication is e-mail)

\section{Word Count:}

4126 (Excluding Abstract and References) 


\begin{abstract}
$\underline{\text { Abstract: }}$
Epilepsy can define who one is rather than the diagnosis one has. It may be considered under the rubric of disability with legislative protection against discrimination. Those seeking remedy should investigate alternative dispute resolution in preference to litigation. Many areas of the life of a person with epilepsy deserve examination when considering epilepsy and law. Just some of these include: duty of care; informed consent; driving; research; social interactions; insurance; recreational pursuits; employment; and privacy. This paper has examined the legal implications and ramification of these selected topics acknowledging that the limited scope of the paper has only exposed the tip of the iceberg to encourage further exploration.
\end{abstract}




\section{Epilepsy and Law}

\section{$\underline{\text { Introduction }}$}

When contemplating a review of epilepsy and law it is a sobering realisation that epilepsy can actually define who one is rather than what one has, namely the diagnosis. This results from the social stigma associated with epilepsy $(1,2)$ which differs with the stage of life that the person is experiencing (3) and the person's gender (3). It dictates the need for advocacy for the person with epilepsy, which involves legal representation in many aspects of that person's life (4). To accommodate such needs there have been a number of legislative interventions that were designed to support those with disability, or those subject to discrimination, in such areas as employment or education (5-9). Application of these statutes incorporates protection for those with epilepsy.

The idea that a person may be identified as an "epileptic", rather than 'a person with epilepsy', is not a new development and has been actively resisted by all those who have been involved in the care of those with epilepsy for many years (10-11). The above cited statutes have provided vehicles by which a person with epilepsy can seek remedy should he/she perceive that there has been improper management of circumstances predicated by the fact that the individual has been diagnosed with epilepsy. In an article such as this, it is inappropriate to offer detailed legal advice as to how to achieve such remedies. What is appropriate is to acknowledge that there is statutory protection; that there is opportunity to seek restitution; and should a person with epilepsy feel need to seek remedy then he/she should seek legal advice.

There is a legal dogma that advocates against litigation because of the costs and stress associated with such action (12-13). This should not be interpreted by the person as a blanket denial of that person's legal right to go to court but rather the need for due diligence and deliberation before seeking remedy by litigation.

Litigation is not the only avenue to seek restitution. Mediation, conciliation, direct negotiation and the intervention of external advocates, such as the national epilepsy body, such as the American Epilepsy Foundation or Epilepsy Australia or their equivalent, may achieve an equitable outcome without need for court appearances (14-15). This avoids the inherent costs (financial and emotional) and the lack of predictability which always attaches to any litigation.

One of the real benefits of representative epilepsy organisations is to act as an advocate for people with epilepsy (16-17). They also hve a role to monitor statutory standards designed to protect the legal rights of people with epilepsy (17-18). They also offer the opportunity to lobby for change where such change is necessary to maintain statutory protection (17-19). 
On an individual level such representative bodies can advise a person with epilepsy of his/her legal rights (20). Acknowledging that such organisations often do not include a legal department, the organisation still may be able to offer the person with epilepsy a referral to affordable legal advice or access to a receptive lawyer who is known to be willing to assist people with epilepsy. It would be valuable for such an organisation to also have information on the capacity of such lawyers to represent people with epilepsy, based on experience and standing within the area of legal dispute. If the organisation cannot offer such advice the individual with epilepsy should ask for such information, from the lawyer, before engaging that lawyer. The person with epilepsy, as should all people seeking legal advice, must be satisfied that the lawyer is qualified and capable to provide the advice sought and to represent the person in any subsequent legal action and to do so to that person's optimal advantage (21).

Discussion thus far has focused on statutory protection and application via the courts but much of the interface of epilepsy and law is via rules, regulations and "judge-made" law, in common law jurisdictions (22). It must be acknowledged that much European law is via civil law of Roman origin (23) rather than the British origins, the latter prevailing in countries like the Unites States of America, United Kingdom, Canada and Australia. Civil law is reliant more on codes and their application rather than judicial precedence (24-25).

\section{$\underline{\text { Some Specific Areas of Concern }}$}

\section{Duty of Care}

Epilepsy and the law can be approached from a number of perspectives and this review has adopted that of the patient, rather than the carer. The carer has definite legal responsibility to the patient known as the 'duty of care' (26) in which the carer is expected to provide optimal care, within his/her level of competence. Such care must respect the ethical and clinical standards of medicine necessary to accommodate the patient's needs (27).

Duty of care is not restricted to clinical management and includes research obligations (as discussed below) and the need to respect a patient's privacy (also discussed below). Should a patient seek remedy concerning a doctor's failure to provide adequate care there are a number of potential avenues. In Australia, since the Ipp Report (28), there has been a significant tort law reform which has restricted the capacity to seek damages within the legal system.

Where the patient perceives the doctor has acted inappropriately or improperly there is a complaints process, such as the Health Care Complaints Commission (29). Such bodies have been established to protect patients' rights and to monitor the level of service provision. They are designed to provide an inexpensive and impartial method to investigate complaints and institute action as may be required consequent to such examination. Some systems seek fault while others, such as the New Zealand System 
(30), work on a no-fault basis designed to compensate patients without need to litigate against doctors to establish fault. As has already been stated, litigation should always be the last avenue, when alternative dispute resolution has failed. Even in the New Zealand system (30), the actions of the carer will be evaluated to ensure that unacceptable behaviour is not allowed to continue and where a carer requires rehabilitation to reestablish adequate standards then this will be properly instituted.

Duty of care is the overarching responsibility to ensure patients have access to good clinical management that respects their rights as individuals with a chronic condition such as epilepsy.

\section{Informed Consent}

Informed consent has been considered under a separate heading to emphasise that it is a fundamental component of all patient care (31). It is axiomatic to state that patient care is the compromise between what the carer offers, by way of treatment, and what the patient accepts. Acceptance is predicated on the assumption that the patient has been offered with the necessary information upon which to base a decision. Such information must include the material risks attached to the treatment, namely those facts without which a patient cannot make an informed decision (32-34).

Where the provision of detailed information will not alter the outcome for the patient, even if that outcome is negative, then failure to provide such information cannot be deemed to represent negligence due to the withholding of information classed as material. This is based on the understanding that patient behaviour, subsequent to appreciating the facts, could not change what occurred. Such issues were reviewed within the context of sudden unexplained death in epilepsy (SUDEP) and interpreted such that failure to discuss SUDEP could not amount to negligence as the discussion would not alter the outcome (35).

Further broad discussion of informed consent is covered in the various topics below. As has already been stated, informed consent is the foundation upon which patient management is built and thus its discussion permeates all other factors relevant to patient care.

\section{Epilepsy and Driving}

Driving is often assumed to be an integral part of modern living but it is denied to people with active epilepsy, other than those who only have nocturnal seizures (36-38). It seems common sense to assume that if a person is prone to seizures, which can interfere with consciousness and contact with the surroundings, then driving is not only a hazard to the person with epilepsy but also to all other road users.

It follows that if a doctor knows that a person with epilepsy is driving, contrary to medical advice, then that doctor has a duty of care, both to the patient and to the 
community, to report that patient to the driving authorities (39-42). In some jurisdictions the reporting of patients with epilepsy is mandated within the applicable statues $(36,43-$ $44)$ although this is far from universal (36, 46-49). In most jurisdictions the doctor is indemnified from reporting patients to the driving authorities, assuming such an act was performed in good faith $(40,44,47,50)$. Again this is also not universal $(47,51)$ and in some jurisdictions the doctor is neither forced to report such patients nor is he/she protected from action for invasion of privacy by doing so $(47,51)$.

Despite doctors, particularly neurologists, endorsing the need to report recalcitrant patients, research has shown that few actually do so regularly (52). This highlights the fact that the law can intrude into the doctor-patient relationship. It is the basis of this relationship which leads many doctors to argue most strongly against the mandatory reporting of people with epilepsy to the authorities (53-54). It is argued that such impost results in patients concealing their true seizure frequency $(45,55-57)$ and may result in 'doctor shopping' in the hope of finding a more sympathetic doctor who will refuse to comply with the law.

Different jurisdictions impose different seizure-free periods for different types of epilepsy (37-38, 44, 46, 58-61). They usually deal with private road users and commercial drivers who have epilepsy, with a different set of restrictions based on different risk factors due to the time spent driving, the size of the vehicle being driven and the cargo being transported (38, 47, 54, 62-63).

It has been shown that doctors are often excessively sympathetic to their patients and may consider the restrictions imposed by the authorities to be more than is appropriate (52). This, together with reticence to report patients, despite there being clear reason to do so, may cause the attendant physician to be personally liable to litigation by injured third parties should it be shown that the doctor acted without due diligence to the accepted duty of care to the wider community $(4,47,64)$.

Patients may also be found guilty of dangerous driving if they fail to report their epilepsy to the authorities and subsequently have an accident (65).

Doctors are often ignorant of the guidelines regarding epilepsy and driving (66). This lack of awareness may result in doctors failing to honour their legal obligation although it must be realised that ignorance is a poor defence against action for inappropriate conduct (67). It follows that doctors need to know the local regulations that apply to epilepsy and driving and their obligations to report to authorities. These same doctors must also appreciate what protection is in place should they report their patients in contravention to codes of privacy that may apply.

\section{Involvement in Research}

An area often confronting doctors dealing with patients who have epilepsy is their involvement in research. There are standard rules that pertain to all patients who are 
recruited to clinical research. There is a need to respect good clinical practice (68-69); there must be a human research ethics committee or institutional review board tasked with the responsibility to evaluate such a study (70-71); patients must have the capacity to consent to involvement within a trial (72-73); there is the need to obtain informed consent prior to inclusion (74-75); and there are a variety of ethical issues that must be addressed (76-79).

Epilepsy may be associated with intellectual handicap, as is the case with Lennox Gastaut Syndrome (80). Involvement of this type of patient, within any clinical relationship, irrespective of whether it is for research or just providing patient care, necessitates special protection of that patient's rights. Many jurisdictions have established Guardianship Boards specifically designed to ensure that such intellectually handicapped patients are not exploited $(74,81)$. These boards act in addition to ethics committees to give enhanced protection for those who cannot protect themselves $(74,81)$. They will review requests for involvement in research, changes in treatment regimen and will ensure that the suggested options are in the patient's best interests (74).

It is imperative that all research involving people with epilepsy respects the international conventions $(69,76)$ designed to protect human subjects within studies. The project must have scientific validity (81); be achievable (82); and avoid, as far as possible, risk of harm to the enrolled subjects. Such considerations transcend the obligations restricted to epilepsy related projects and comprise the basic responsibilities of all investigators who experiment with human subjects. Thus, further consideration of these issues will not be addressed other than to acknowledge that no research is without risk. It is inherent upon the researcher to ensure that the subjects, the researchers and their delegates, as well as the review boards, are all individually and collectively indemnified should an adverse outcome ensue from the study (83).

\section{$\underline{\text { Social Interaction }}$}

The introduction referred to potential statutory protection for people with epilepsy. This covers such issues as discrimination but it was not that long ago that there were legal barriers which precluded people with epilepsy from marrying (84-85) and being properly integrated into society (86).

It has long been recognised that rates of marriage may be lower (87) and divorce may be higher for those who have epilepsy (88-89). Carran et al have argued that better seizure control for women may alter their dependence on a husband thereby altering marital dynamics (90). It follows that better seizure control can also result in marital discord which may lead to higher rates of divorce. As the laws affecting divorce have universally become more liberal $(85,91)$, especially in western society, an unexpected consequence of better seizure control may be an accelerated rate of marital dissolution rather than perseverance and trying to sort out interpersonal disharmony within the marriage. 


\section{$\underline{\text { Travel }}$}

Recently a patient was refused a booked and paid seat on a commercial airline because it was discovered that he had experienced a seizure within the preceding 24 hours (92). This was despite that man, an intellectually handicapped man in his 30's, being a seasoned traveller who was accompanied by his mother (aged in her 50's, capable and willing to render first aid if needed) and the patient being his normal self at the time of proposed travel. His mother had no right of redress due to "small print" in the ticketed contractual relationship with the airline, and was forced to pay for an extra night's accommodation, delay her plans and she was made to feel disempowered. It follows that, while many believe legal impediment to a full quality of life has been removed, there remain areas that demand further attention without which such overt unreasonable discrimination remains legally enforceable.

Only with forceful and vocal advocacy will such inequities be changed. There has been legal precedence with the 'ticket cases', concerning parking cars (93), in which the providers of a service can rely on 'small print' on a ticket, although the person with epilepsy might be excused to have thought it is almost inconceivable that similar legal constraints can prevent a person with epilepsy being a passenger on a one hour flight, as this case has demonstrated.

\section{$\underline{\text { Insurance }}$}

Insurance is something that most people take for granted to allow them to protect themselves and their families against possible adverse occurrences. The above cited case would be an example in which travel insurance would identify epilepsy as a pre-existing condition which would then become exempt from cover within the insurance contract.

As has been stated by the IBE Commission on Epilepsy, Risks and Insurance (94), “...In general, only patients with mild epilepsy can be insured, which means no or few attacks with or without medication for a period of 2-5 years. A policy will usually include an added clause covering impairment for epilepsy...”.

The consequence of such policies is based on probability calculations designed to minimise the 'payouts' by the insurer which reflects a commercial decision devoid of humanitarian considerations. A study by Thorbecke found that drivers with epilepsy who complied with applicable laws could obtain insurance similar to non-epilepsy affected drivers (94). Life insurance carries an additional premium to compensate for the commercial reality of increased risk but disability insurance is far less available. A third of surveyed companies insisted upon individual risk assessment (94) with many either totally excluding people with epilepsy or removing those specific epilepsy-related disabilities from the provided insurance cover (94).

Insurance policies represent a legal contractual relationship between the insurer and the insured. There is no imperative to force an insurer to cover the risks posed by the 
proposed client. Commercial reality acts against the interests of the insured in favour of the insurer and application of the law cannot force an insurer to be placed in a disadvantaged position. This demonstrates just one of the many circumstances in which the person with epilepsy must accept that their medical status imposes legal constraints that others take for granted.

\section{$\underline{\text { Recreational Pursuits }}$}

The person with epilepsy is denied some recreational activities by law. These include competitive driving (95), diving (96), flying (97) and other activities which require medical examination and certification to be considered fit to perform the activity. The restrictions are usually as a consequence of regulations which attach to statutes. This means that the laws are neither made by parliament (or its elected equivalent) nor judgemade law, as per common law jurisdictions. They are rules imposed by regulatory authorities appointed by parliament, usually via a statute, which allow far greater flexibility to set arbitrary guidelines (98).

As a rule, these constraints are put in place to protect the person with epilepsy from self harm or the potential to harm others. The restrictions are not necessarily evidence-based but often are the result of opinion leaders advising government agencies of perceived hazards, often devoid of reliable evidence-based information upon which to formulate such advice. Fear of litigation may result in the imposition of restrictions which appear punitive, once they are examined with recognition of the vacuum of available information upon which they are developed.

Of late, there has been some realisation that such restrictions may be ill conceived. An example of this has been the Civil Aviation Safety Authority in Australia which has advised that it is prepared to consider each case on its merit regarding epilepsy and flying as a pilot (99). This may allow a pilot who has very well controlled epilepsy to fly a plane in which there is a co-pilot available should a seizure occur (99).

There are some activities which the person with epilepsy should generally avoid - such as mountain climbing, abseiling, carabining or sky-diving. Even if these activities may not be legally prohibited the person with epilepsy owes it to others undertaking these activities to at least advise them of the potential for seizures within these circumstances. Where there is a foreseeable risk to harm others it follows that there is a duty of care to advise those others of such risk when joining the person with epilepsy in the activity. It is unreasonable to refuse others the same right of informed consent that is expected by the person who has epilepsy when undertaking non-essential recreational activities in their company and which pose additional risks to others.

\section{Employment}

It has already been discussed that overt, unreasonable discrimination against people with epilepsy is prescribed by legislation but that does not totally remove discrimination. 
Jacoby et al (100) identified persistent barriers to the employment of people with epilepsy although they perceived there to be some improvement. It is problematic to seek legal remedy for perceived discrimination as employers are not compelled to nominate why a prospective employee was denied the job.

Unemployment for those with epilepsy seems double the community rate (101-102).

This may be as a consequence of lack of seizure control or associated degenerative deficit (100). There are some forms of employment which are legitimately denied to those with epilepsy and the restriction is legally enforceable. As a rule of thumb such occupations, as require the employee to wear a uniform, are widely denied to those with epilepsy. An example of this is service within the armed forces (103). While the rationale behind such exclusion may be ill founded the restriction is usually reinforced by statute which precludes application of antidiscrimination laws (103).

The question of pilots has already been discussed with consideration concerning legal requirements to be allowed recreational flying, the same is not as flexible for commercial pilots (104). Service within the police force or fire service is usually denied, citing the same constraints as apply to military service (105-106). These occupations usually include a minimum medical standard as part of their employment contract and the presence of epilepsy causes the applicant to fall below such standards (105-106).

While it may be possible to appeal a decision to be denied employment, such appeals are costly in time, effort and emotional expenditure, let alone the already alluded to inordinate cost of litigation which may apply. It follows that many people with epilepsy will be denied their vocational ambition and will accept underemployment (107-109). Only with a public education programme can one hope to over come what amounts to wide-spread misconceptions which covertly inhibit the aspirations of those with epilepsy (110).

\section{Privacy}

The question of disclosing epilepsy is a perennial issue which has wide ranging ramifications $(42,54,111)$. A person's privacy is subject to legislative protection with many jurisdictions enacting privacy laws (112-113).

Concealing epilepsy may amount to an illegal act - such as falsely completing an application for a driver's licence (66). It may also result in harsh penalty if it is perceived that such concealment resulted in the inappropriate issuance of a driver's licence which subsequently caused an accident that injured or killed others (67).

Invasion of privacy may be mandated by law (42-44). There may be legal indemnification for the doctor or health professional who reports someone with epilepsy to the authorities and does so in good faith $(47,49-50)$. While many doctors acknowledge the need to report patients who pose a risk, in reality few actually respect this position (52) thereby emphasising the priority of the doctor-patient relationship (42, 
114). Such reticence to report an 'at risk' patient may place the doctor at risk for failure to recognise a duty of care to the wider community and may see that doctor face criminal charges in the case of death occurring due to failure to disclose the patient's status or civil action to compensate for third party damage (65-66).

Privacy provides an ideal topic with which to complete an overview of the interface between epilepsy and the law. To consider the issue of privacy, within the medical model, one need not stray far from the accepted roots of western medicine and the Hippocratic Oath (115).

To quote the oath:

“...whatever in connection with my professional practice, or not in connection with it, I see or hear, in the life of men, which ought not be spoken abroad, I will not divulge, as reckoning that all should be kept secret...”.

\section{$\underline{\text { Conclusion }}$}

In a paper, such as this, it is impossible to cover all aspects relating to epilepsy and the law. In reality it is impossible to travel too far beyond a single legal edifice, be it common law, civil law or an alternative legal system as may be dictated by religious conviction. This paper has focused largely on common law considerations.

Within common law there exists legislative, statute law in which the government has implemented binding rules beyond which the judiciary cannot stray. There is also precedent based judicial interpretation in which judges make laws within the broad framework of legislative power but where legislation has failed to prescribe or proscribe defined behaviour, thereby allowing judicial prerogative. There are also rules and regulations imposed by government agencies which are neither fully scrutinised by legislators nor subjected to judicial review prior to application.

One cannot ignore the fact that application of the law is not always straightforward. In an adversarial system, as applies in common law, the actual true legal position may be less clear than the casual observer may think is the case and will only become truly clear once it has been tested in a court. It is definitely not as predictable as many claim it to be and thus alternative dispute resolution may allow greater certainty for all concerned. It follows that this review paper has exposed just the tip of the iceberg that is the interface between epilepsy and the law and has examined just a few of the relevant topics with the hope of generating sufficient interest to encourage further exploration of this fascinating topic.

\section{Acknowledgements:}

I would like to thank Annaliese Hurley for her assistance in preparing this paper. 


\section{References:}

1. Amoroso C, Zwi A, Somerville E, Grove N. Epilepsy and Stigma. The Lancet 2006; 367 (9517): 1143-4.

2. Jacoby A, Snape D, Baker GA. Social Aspects: Epilepsy Stigma and Quality of Life. Epilepsy - A Comprehensive Textbook. Volume Two. J. Engel Jr. and TA Pedley (eds) Lippincott-Raven, Philadelphia, 2008, pp. 2229-2236.

3. Hills M. "Gender specific psychological issues through the eyes of the person with epilepsy” $27^{\text {th }}$ International Epilepsy Congress ILAE \& IBE Abstracts, Singapore 2007, p 18.

4. Beran RG, Devereux JA, McLin W, Lehman C, Falk-Pedersen J, de Boer HM, Finucane A. Legal concerns and effective advocacy strategies. Epilepsy - A Comprehensive Textbook. Volume Three. J. Engel Jr. and TA Pedley (eds.) Lippincott-Raven, Philadelphia, 2008, pp. 2277 - 2282.

5. Disability Discrimination Act 1992 (Cth), Australia.

6. Anti-Discrimination Act 1992 (Qld), Australia.

7. Anti-Discrimination Act 1977 (NSW), Australia.

8. Americans with Disabilities Act. 42 U.S.C. 12101 et seq 1990, America.

9. West MD, Dye AN, McMahon BT. Epilepsy and workplace discrimination: population characteristics and trends. Epilepsy Behav. 2006; 9 (1): 101-5.

10. Dickson E. Disability Discrimination in Education: Purvis v New South Wales (Department of Education and Training), amendment of the education provisions of the Disability Discrimination Act 1992 (Cth) and the formulation of Disability Standards for Education. 2005. UNSWLJ11, 2005; 24(1), University of QLD Law J 213.

11. Sutton C, Beran RG. The role of the health system in reducing the stigma attached to epilepsy. Aust. J Soc. Issues, 1983; 18: 203-208

12. Barton A. Medical litigation: Who benefits? BMJ 2001; 322: 1189

13. Ferris LE. Alternative dispute resolution and disputes concerning physicians' practices or services. Medicine and Law 2004; 23(1): 147-148.

14. Avitzur, O. Know your rights. Neurology Now 2007; 3(5): 34-7.. 
15. "Questions and Answers for Mediation Providers: Mediation and the Americans with Disabilities Act (ADA)”. U.S. Equal Employment Opportunity Commission, National Council on Disability, U.S. Depatment of Justice. May 10, 2005. Accessed 4 December 2007 at: http://www.eeoc.gov/mediate/ada/ada_mediators.html

16. Gumnit RJ. Comprehensive Epilepsy Programs - United States. Epilepsy - A Comprehensive Textbook. Volume Two. J. Engel Jr. and TA Pedley (eds.) Lippincott-Raven, Philadelphia, 2008, pp. 2937-8.

17. Avitzur O. How to advocate for our disabled patients in the workforce. Neurology Today 2007; 7(15); 18-19.

18. Barnes H, Thornton P, and Maynard-Campbell S, Disabled People and Employment: A Review of Research and Development Work, York: The Joseph Rowntree Foundation, 1998, pp 6-13.

19. Shaw G. New Congress, New Fundraising for NIH? Not Necessarily. Neurology Today 2006; 6(24): 18-19.

20. Gumnit RJ. Living well with epilepsy. $2^{\text {nd }}$ ed. New York: Demos Vermande, 1997, pp. 215-6

21. "Find a lawyer" and "Your relationship with your lawyer”. Law Society of NSW, Accessed 4 December 2007 at: http://www.lawsociety.com.au/page.asp?partID=15278

22. Meek M. The Australian Legal System. Third Ed. LBC Information Services, Sydney, 1999, pp. 117-126.

23. Falk-Pedersen J. Automatisms in non common law countries. Medicine and Law 1997; 16: 359-65.

24. Dainow J. The role of Judicial Decisions and Doctrine in Civil Law and in Mixed Juristictions. The Americal Journal of Comparative Law 1976; 24(1): $113-8$

25. Beran RG. Legal Aspects of Epilepsy. Seizure 2002; 11: 211-6.

26. Beran RG. Epilepsy: Duty of Care. Tel Aviv. Yozmot 2000.

27. Devereux JA. Epilepsy - a legal perspective on obligations owed to patients by medical practitioners. Medicine and Law 2002; 21(4): 753-67. 
28. Ipp DA. Review of the Law of Negligence. Commonwealth of Australia, Canberra; 2002.

29. Health Care Complaints Act 1993 (NSW), Australia

30. Bismark MM, Dauer EA. Motivations for medico-legal action: lessons from New Zealand. Journal of Legal Medicine 2006 ;27: 55-70.

31. Beran RG. Informed consent, a legal requirement in the management of patients with epilepsy. Medicine and Law 2003; 22(1): 155-84.

32. $\quad$ Rogers $v$ Whitaker (1992) 175 CLR 479; (1991) Aus Torts Reps 81-113 (NSW CA); (1991) 23 NSWLR 600.

33. Chappel v Hart (1998) 156 ALR 517.

34. NSW Dept of Health - File No 97/483 Circular 99/16, $18^{\text {th }}$ February 1999.

35. Beran RG, Weber S, Sungaran R, Venn N, Hung A. Review of the legal obligations of the doctor to discuss sudden unexplained death in epilepsy (SUDEP) - A cohort controlled comparative cross-matched study in an outpatient epilepsy clinic. Seizure 2004; 13(17): 523-28.

36. Assessing Fitness To Drive - Commercial \& Private Vehicle Drivers: Medical Standards for Licensing and Clinical Management Guidelines. AUSTROADS \& National Road Transport Commission, Sydney 2001 (reprinted September 2003 and 2006)

37. Devereux JA. Epilepsy and Driving Licences. Medicine and Law 2002; 21: 121-32.

38. Beghi E, Sander JW. Epilepsy and Driving - Regulations in the European Union need harmonisation as well as greater flexibility. BMJ 2005; 331: 60-61.

39. McSherry B. Epilepsy and confidentiality: Ethical considerations. Medicine and Law 2004; 23: 133-145

40. Black AB. Confidentiality - Confidentiality and driver licensing authorities. Medicine and Law 2003; 22(2): 333-44

41. Beran RG. Confidentiality and the management of patients who fail to comply with doctor's advice not to drive: a survey of medico-legal opinions in Australia. Seizure 1998; 6:1-10. 
42. Jozefowicz TH. The case against having 'Professional Privilege' in the physician/patient relationship. Medicine and Law 1997; 16(2): 385-94.

43. Mclachlan RS. Medical Conditions \& Driving: Legal Requirements \& Approach of Neurologists. Medicine and Law 1997; 16(2) 269-276.

44. Fisher RS, Parsonage M, Beaussart M, Bladin P, Masland R, Sonnen AE, Remillard G. Epilepsy and driving: an international perspective. Joint Commission on Drivers' Licensing of the International Bureau for Epilepsy and the International League Against Epilepsy. Epilepsia 1994; 35: 675-84.

45. Black AB, Lai NY. Epilepsy and driving in South Australia: an assessment of compulsory notification. Medicine and Law 1997; 16(2): 253-67.

46. Ooi WW, Gutrecht JA. International Regulations for Automobile Driving and Epilepsy. J Travel Med 2000; 7: 1-4.

47. Beran RG. An analysis and overview of the guidelines for assessing fitness to drive for commercial and private vehicle drivers. Int Med J. 2005; 35: 364-8.

48. McLachlan RS, Starrevels E, Lee MA. Impact of Mandatory Reporting on Accident Risk in Epilepsy. Epilepsia 2007; 48(8): 1500-5.

49. Finucane AK. Legal aspects of epilepsy. Neurol. Clinics 1999; 17: 235-43.

50. Lipman IJ. Consensus Conference of Driver Licensing and Epilepsy: American Academy of Neurology, American Epilepsy Society, and Epilepsy Foundation of America. Epilepsia 1994; 35(3): 662-4.

51. Western Australia Road Traffic Act 1974 s.42(4)

52. Beran RG, Ainley LAE, Beran ME. Opinions, attitudes and practices of Australian neurologists with regards to epilepsy and driving. Internal Med J. 2007; 37 (4): 251-7.

53. Gromb S. Maintenance of professional privilege as exists in France. Medicine and Law 1997; 16(2): 395-404.

54. Hocking B, Landgren F. New medical standards for commercial and private drivers. MJA 2003; 179(6): 276-77.

55. Jang RW, Man-Son-Hing M, Molnar FJ, Hogan DB, Marshall SC, Auger J, Graham ID, Korner-Bitensky N, Tomlinson G, Kowgier ME, Naglie G. Family Physicians' Attitudes and Practices Regarding Assessments of Medical Fitness to Drive in Older Persons. J Gen Intern Med 2007; 22(4): 531-43. 
56. Salinsky MC, Wegner K, Sinnema F. Epilepsy, Driving Laws, and Patient Disclosure to Physicians. Epilepsia 1992; 33(3): 469-72.

57. Dalrymple J, Appleby J. Cross sectional study of reporting of epileptic seizures to general practitioners. BMJ 2000; 320(7227): 94-7.

58. Krumholz A, Fisher RS, Lesser RP, Hauser WA. Driving and epilepsy : a review and reappraisal. JAMA 1991; 265: 622-626.

59. Krauss GL, Ampaw L, Krumholz A. Individual state driving restrictions for people with epilepsy in the US. Neurology 2001; 57: 1780-85.

60. Ben-Menachem E. Toward a more pragmatic view of driving and epilepsy. Epilepsy Curr 2004; 4(4): 133-4.

61. Krauss GL. Frumholz A, Carter RC, Li G, Kaplan P. Risk factors for seizurerelated motor vehicle crashes in patients with epilepsy. Neurology 1999; 52: 1324.

62. Federal Motor Carrier Safety Administration. Part 391: qualifications of drivers and longer combination vehicle (LCV) driver instructors. Subpart E-physical qualifications and examinations. Physical qualifications for drivers. United States Department of Transportation. Accessed December 3, 2007, at: http://www.fmcsa.dot.gov/rulesregulations/administration/fmcsr/fmcsrruletext.asp?section=391.41.

63. Adams SM, Knowles PD. Evaluation of a first seizure. American Family Physician 2007; 75(9): 1342-7

64. Hurley D. When epileptic patients crash: Legal airbags protect most neurologists but buckle your seat belt just the same. Neurology Today 2007; 7(2): 18-19.

65. Beran RG, Devereux, JA. Road not taken: lessons to be learned from Queen v. Gillett. Int Med J. 2007; 37(5): 336-9.

66. Shanahan EM, Sladek RM, Phillips P. Medical aspects of fitness to drive. What do public hospital doctors know and think? Int Med J. 2007; 37(6): 372-376.

67. Beran RG. In response to "Letter to the Editor: Medical aspects of fitness to drive. What do public hospital doctors know and think.” By Shanahan et al. Int Med J. (In Press) 
68. National Health \& Medical Research Council. National Statement on Ethical Conduct in Human Research. Cth of Australia, 2007.

69. Beyleveld D. Law, Ethics and Research Ethics Committees. Medicine and Law 2002; 21 (1): 57-75.

70. Alexander JI. Multicentre research ethics committees. J Roy. Soc. Med 1999; 92: 662.

71. Larcombe I, Mott M. Multicentre research ethics committees: have they helped? J. Roy. Soc. Med 1999; 92: 500-501.

72. Mozes T, Tyano S, Manor I, Mester R. Informed Consent: Myth or Reality. Medicine and Law 2002; 21(3): 473-483.

73. Wirshing DA, Wirshing WC, Marder SR, Liberman RP, Mintz J. Informed Consent: Assessment of Comprehension. Am J Psychiatry 1998; 155: 1508-11.

74. Devereux JA. Guardianship and consent. Medicine and Law 2004; 23(2): 35965.

75. Yank V, Rennie D. Reporting of Informed Consent and Ethics Committee Approval in Clinical Trials. JAMA 2002; 287: 2834-38.

76. World Medical Association Declaration of Health, Helsinki (1989) Recommendations Guiding Physicians in Biomedical Research Involving Human Subjects, Adopted by the $18^{\text {th }}$ World Medical Assembly, Helskinki, Finland, June 1964 and amended by $29^{\text {th }}$ World Medical Assembly, Tokyo, Japan, Oct 1975; $35^{\text {th }}$ World Medical Assembly, Venice, Italy, Oct 1983; $41^{\text {st }}$ World Medical Assembly, Hong Kong, Sept 1989; $48^{\text {th }}$ General Assembly Somerset West, Republic of South Africa, Oct 1996; $52^{\text {nd }}$ World Medical Assembly Edinburgh, Scotland, Oct 2000; Note of Clarification on Paragraph 29 added by the World Medical Assembly General Assembly, Washington 2002; Note of Clarification on Paragraph 30 added by the World Medical Assembly General Assembly, Tokyo 2004.

77. Tri-Council Policy Statement. Ethical Conduct for Research Involving Humans. Ottawa, Canada, MRC, August 1998, with 2000, 2002 and 2005 amendments.

78. Berglund C. Ethics: a process for reflection. Medicine and Law 2003; 22(4): 635-46.

79. Cramer J. Ethical issues in the planning and conduct of clinical trials of antiepileptic drugs. Medicine \& Law 1997; 16: 209-14. 
80. de los Reyes E, Sharp G, Williams J, Hale s. Levetiracetam in the treatment of Lennox-Gastaut syndrome. Pediatric Neurology 2004; 30(4): 254-56.

81. Beran RG. Ethical considerations within clinical research with special focus upon clinical drug trials. Medicine and Law 2005; 24: 411-36.

82. Miller FG, Shorr AF. Ethical Assessment of Industry-Sponsored Clinical Trials - A Case Analysis. Chest 2002; 121: 1337-1342,

83. National Health and Medical Research Council, Discussion Paper on the Legal Liability, Insurance and Indemnity for Institutional Ethics Committees, (1993) Australian Government Publishing Service

84. Shostak S, Ottman R. Ethical, Legal, and Social Dimensions of Epilepsy Genetics. Epilepsia 2006; 47(10): 1595-1602.

85. Mani KS. Epilepsy: Legal discrimination from negative to positive. Medicine and law 1997; 16(2): 367-74

86. Masia SL, Devinsky O. Epilepsy and Behavior: A Brief History. Epilepsy \& Behavior 2000; 1(1): 27-36.

87. Dansky LV, Andermann E, Andermann F. Marriage and fertility in epileptic patients. Epilepsia 1980; 21(3): 261-71.

88. Collins JA. Psychological well-being and epilepsy: An empirical study. Epilepsia 1990; 31: 418-26.

89. Taylor DC, Falconer MA. Clinical, socio-economic, and psychological changes after temporal lobectomy for epilepsy. Br J Psychiatry 1968; 114: 1247-61.

90. Carran MA, Kohler CG, O’Connor MJ, Cloud B, Sperling MR. Marital statutes after epilepsy surgery. Epilepsia 1999; 40: 1755-60.

91. Santosh D, Kumar TS, Sarma PS, Radhakrishnan K. Women with onset of epilepsy prior to marriage: Disclose or Conceal? Epilepsia 2007; 48(5): 100710.

92. Personal Communiqué's - deals with a case within the author's practice unreported.

93. Heffey P, Paterson J, Robertson A. "Ticket cases” in Principles of Contract Law. Lawbook Co, Sydney 2002, pp. 58-9. 
94. Beghi E, Brown S, Capurro D, Chadwick D, Cornaggia CM, De Boer H, Garattini L, Hauser A, Homsma SJ, Lazazzera M, Sillanpaa M, Sonnen AE, Thorbecke R. IBE Commission Report. $2^{\text {nd }}$ Workshop on "Epilepsy, Risks, and Insurance”. Epilepsia 2000; 41(1): 110-2.

95. Confederation of Australian Motor Sport (CAMS) Medical Standards. $1^{\text {st }}$ Impression September 1989. p. 4

96. Wilks J. Scuba Diving and Snorkeling Safely on Australia’s Great Barrier Reef. J Travel Med 2000; 7:283-289.

97. Designated Aviation Medical Examiner’s Handbook. Phillip, ACT, Australia. Civil Aviation Safety Authority; 2003.

98. The Legislative Instruments Act 2003, Australia

99. Hosegood I. Principle Medical Officer CASA Personal communique.

100. Jacoby A, Gorry J, Baker GA. Employers’ attitudes to employment of people with epilepsy: Still the same old story. Epilepsia 1005; 46: 1978-87.

101. Hauser WA, Hesdorffer DC. Epilepsy; Frequency, causes and consequences. Epilepsy Foundation of America 1990. Chapt 8. Employment pp 273-96.

102. Fisher RS, Vickery B, Gobson E. Hermann B, Penovich P, Scherer A, Walker S. The impact of epilepsy from the patient's perspective I. Description and subjective perceptions. Ep. Research 2000; 41: 39-51.

103. Beran RG. Epilepsy and the defence forces. ADF Health, 2004; 5(2): 85-88.

104. Civil Aviation Safety Regulations 1998 (CASR) $1^{\text {st }}$ ed. January 2003, Office of Legal Council, Australia. Part 67. pp21-33.

105. Delany L. Epilepsy, employment and the Disability Discrimination Act. Does Legislation make a difference? Seizure 1999; 8(7): 412-20.

106. Australasian Fire Authorities Council (AFAC) Medical Guidelines for Firefighters. Summary Document. October 2006. pp. 4-12.

107. Chaplin VE, Westen A, Tomson T. Factors associated with employment problems of people with established epilepsy. Seizure 1998; 7: 299-303.

108. Jacoby A, Buck D, Baker G, McNamme P, Graham-Jones S, Chadwick D. Uptake and costs of care for epilepsy: Findings from a UK regional study. Epilepsia 1998; 39: 776-86. 
109. Harden CL, Kossoy A, Vera S, Nikolov B. Reaction to epilepsy in the workplace. Epilepsia 2004; 45: 1134-40.

110. Editorial. Epilepsy education - public education in epilepsy. Epilepsia 2003; 44 (Suppl 6): 64-5.

111. Troster H. Disclose or conceal? Strategies of information management in persons with epilepsy. Epilepsia 1997; 38: 1227-37.

112. Watson D. Familiarising yourself with new federal privacy laws - Risk management. Aust Dr. 2002; 22.

113. Beran RG. Application of Amendments to the Privacy Act (Cth) as They Affect Private Clinical Practice. Medicine and Law 2003; 22(4): 599-612

114. Beran RG. Professional privilege, driving and epilepsy, the doctor's responsibility. Epilepsy Research 1997; 26(3): 415-21

115. Hurwitz B, Richardson R. Swearing to care: the resurgence in medical oaths. BMJ 1997; 315: 1671-74. 